\title{
Are Voters Fiscal Conservatives? Evidence from Brazilian Municipal Elections
}

\author{
- Paulo Roberto Arvate* \\ - Marcos Mendes $\star \star$

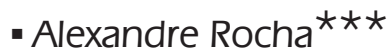

\begin{abstract}
Resumo
Alguns artigos na literatura mostram que os eleitores são conservadores em assuntos fiscais enquanto outros encontram evidências de preferência por uma expansão fiscal. Nós usamos um modelo Probit tradicional para analisar a preferência dos eleitores municipais brasileiros na eleição de 2000. Nosso principal resultado sugere que os eleitores preferem mais gastos. Apresentamos algumas evidências de que esse resultado é uma consequência do modelo de federalismo fiscal existente no qual predomina uma restrição orçamentária fraca para os municípios (contexto institucional). Adicionalmente, obtivemos evidências de que os eleitores com diferentes níveis de escolaridade impõem diferente resultado nos gastos. $O$ efeito do gasto é maior nos municípios onde o nível de alfabetização é menor.
\end{abstract}

\section{Palavras-Chave}

reeleição, governos locais, descentralização, federalismo fiscal

\begin{abstract}
Some papers in literature show that voters are fiscal conservatives, while others find evidence of a preference for fiscal profligacy. We use a traditional Probit model to analyze the preference of Brazilian municipal voters in the 2000 election. The main result suggests that voters prefer greater expenditure. We present evidence that this result is a consequence of a fiscal federalism model where there is a soft budget constraint for municipalities (institutional context). Moreover, we obtained evidence that voters with different levels of schooling impose a different result on expenditure. The effect of expenditure is more marked in municipalities with a low level of literacy.
\end{abstract}

\section{Keywords}

reelection, local government, decentralization, fiscal federalism

\section{JEL Classification}

D72, D78, H72, H77

\footnotetext{
* Professor da FGV-SP e membro do CEPESP (Centro de Estudos de Política e Economia do Setor Público). E-mail: parvate@fgvsp.br.

** Consultor Legislativo do Senado Federal e Doutor em Economia (USP). E-mail: mendes@senado.gov.br.

$\star \star \star$ Consultor Legislativo do Senado Federal e Mestre em Economia (UnB). E-mail: alexroch@senado.gov.br. Endereço para contato: Senado Federal, Anexo II, Bloco B, $2^{\circ}$ andar, sala 7. Brasília - DF. (Recebido em novembro de 2007. Aceito para publicação em setembro de 2009).
} 


\section{Introduction}

One part of political economy literature indicates that voters are fiscal conservatives: they tend not to reelect incumbents who increase expenditure, create deficits, or inflate public debt. However, there are also studies showing that it is possible for incumbents to use fiscal instruments to obtain electoral advantage. In trying to understand why these differences exist, recent works have explored the institutional context of these relations.

Basically, literature on the relationship between fiscal performance and electoral results has been applied to a cross-section of countries and also to a single country's local governments. The strength of the former approach is that it provides mean results that can be generalized for all countries. Its weakness lies in the fact that it is not always possible to control all the institutional and socio-economic differences between the sampled countries (DRAZEN; ESLAVA, 2005). On the other hand, studies of local government elections, such as this, have the advantage of dealing with a smaller constitutional, legal and electoral variation across federative units, thus enabling more accurate results. Still, as noted by Brender (2003) and Brender and Drazen (2005), the results obtained for a country's local governments cannot be generalized for other countries, as they are dependent upon local institutional and socio-economic characteristics that create a framework of incentives and constraints that will drive voter decisions. ${ }^{1}$

This article analyzes the 2000 elections for mayor in Brazil. It shows that voters appear to approve increased spending. Nevertheless, from additional investigations we carried out we understand that this behavior is not part of a typical politicalbudget cycle, in which expenditure increases before elections and a fiscal adjustment occurs at the beginning of the new administration. The Brazilian case appears to be a soft budget constraint phenomenon, in which both voters and mayors have incentives to increase expenditure during the whole term of office, in an attempt to bring in as much money as they can extract from the common pool. In previous work, Nakaguma (2006) shows that Brazilian governors use fiscal instruments to obtain electoral advantage; but, he does not explore the institutional context. Moreover, the 2000 municipal election is also important because it was the first election when all the mayors who assumed office in 1997 could run for reelection; they were not allowed to do so before this.

The Brazilian institutional context has different facets, such as the considerable political weight of local interests in National Congress; the heterogeneity of munici-

1 Arvate, Avelino and Tavares (2009) carried out the same type of investigation for elections for governor. 
palities, which allows a coalition of interests between large and small municipalities, which coordinate their efforts to obtain federal funds; excessive fiscal transfers; the municipalities' ability to manipulate transfer rules; and central government's inability to withstand pressures for bailouts and set effective legal constraints on sub-national indebtedness. The Brazilian case is also important because there is little evidence in Brazilian literature of the importance of the voters' level of education on this process, given that voting is compulsory for adults (between 18 and 60 years old). We have evidence that shows that voters with different educational levels (low literacy) impose different results on expenditure. In municipalities with a low literacy rate, the increase in expenditure in the term appears to have a much stronger effect on mayors' reelection.

Section 2 summarizes the literature that was consulted to help in the development of our work. Section 3 introduces the institutional characteristics of municipal elections in Brazil. Section 4 describes the econometric model adopted and the database used. Section 5 gives the basic econometric results. Section 6 analyzes how heavy dependence on transfers and the educational level can contribute to modify the main results. Section 7 provides comments on additional results and Section 8 concludes the paper.

\section{The Literature that Sustains our Development}

Part of the political economy literature tries to interpret the preference of voters by analyzing fiscal results. Some empirical works focus on local governments (municipalities and states) of a single country, while others compare different countries. Our intention here is to show some of these works and to emphasize the new generation of work that is using the institutional context to justify the differences found. In our view, this line of work can lead to a better understanding of the behavior of Brazilian local voters.

Peltzman (1992) wrote the first important work showing that voters punish US governors who increase spending, regardless of whether this increase is based on deficit or taxes ("spending is the primary bad" - p. 347). It also shows evidence that increased spending on the eve of elections does not fool voters, and that incumbents are punished even more severely when spending increases at the end of their terms. His explanation for this phenomenon is that the tax system is progressive and voters are wealthier than non-voters (the vote is non-compulsory). So, it is the voters who 
foot the bill. He adds that voters are well informed about fiscal data and use this information when casting their ballots. ${ }^{2}$

Drazen and Eslava (op. cit.) argue that well-informed voters are not easily bought by increased spending and are averse to higher levels of spending and deficit. Their investigation concentrates on local governments in Colombia. They further argue that political manipulation takes the form of changes in the composition of government spending, by keeping total spending and the deficit constant. This is due to the fact that voters, albeit rational and forward-looking, lack sufficient information to determine whether the pre-vote spending composition choices that incumbents make are sincere or not; besides, incumbents have more information than voters themselves about the preferences of the majority of voters. These quantitative results indicate an increased probability of reelection when there is increased investment spending and a reduced deficit. Besides, there is no relation between probability of reelection and increased current spending.

By analyzing OECD countries, Alesina et alli (1998) also uphold the argument that voters are fiscal conservatives. Analyzing government replacement (cabinet dismissals in parliamentary regimes or non-reelection in presidential ones), their results

offer no evidence that voters punish governments for reducing deficits. In the case of large adjustments, it seems that if a government relies mostly on spending cuts - and on cuts in government wages, in particular - it is less likely to fall (...) there is no evidence that fiscal profligacy is associated with longer survival in office. (p. 226 e 229).

On the other hand, there is some evidence that the incumbent can benefit from the electoral cycle by using fiscal instruments. Such is the case of the work of Nakaguma (op. cit.) relating to Brazil and Veiga and Veiga (2007) to Portugal. Nakaguma (op. cit.) studies the case of Brazilian state governments and shows that the electorate rewards opportunistic cycles in both revenue and expenditure. ${ }^{3}$ Veiga and Veiga (op. cit.) present other robust evidence of opportunistic fiscal cycles when analyzing the case of Portuguese municipalities. They show that increases in investment expenditure and changes in the composition of spending in favor of highly visible items are associated with a higher percentage of votes for incumbent mayors seeking re-election.

2 Note that US State Constitutions limit state indebtedness and that the public debt market severely punishes governments that are declared bankrupt. These institutional circumstances certainly help voters evaluate incumbents.

3 He does not explore the institutional context to define voter preference. 
There are authors who argue that the fiscal conservativism of voters depends on the institutional context in which the elections occur. The sets of constraints and incentives imposed on governments and voters appear to make a difference. Analyzing the case of local governments in Israel, Brender (op. cit.) suggests that in the 1989 and 1993 ballots fiscal performance had no bearing on the probability of reelection for mayor, but that the situation had shifted in 1998, when voters rewarded more conservative fiscal stances. He argues that this was the result of institutional evolution, such as: central government-mandated audits, detailed fiscal statements (improving voter information levels), increased circulation of local newspapers, more relevant information available to voters; and the imposition of a tighter budget constraint (an end to financial rescue operations and an adjustment program, with the last rescue operation, carried out in 1997-99, signaling a change in the rules of the game). Analyzing 1998 data only, Brender (op. cit.) further concludes that voters punish mayors who pay higher-than-average wages, as well as those showing feeble tax collection efforts. As far as concerns the composition of expenditure, he finds a result similar to Drazen and Eslava (op. cit.), revealing that voters reward a budget that is biased towards capital expenditure. Moreover, he shows that no differences in the probability of reelection are linked to the socio-economic level of the local community (which differs from the result we obtained for Brazil).

The institutional idea is reinforced by Akhmedov and Zhurasvskaya (2004). They show that Russia, an "immature democratic regime", has significant and robust opportunistic fiscal cycles. They argue that "Russian democracy is very young and many regions are notorious for governor's control over mass media and large fraction of uninformed, naïve and myopic electorate (...) poor voters (...) are the primary target of the cycle [because they] have the worst possibilities for consumption smoothing. (...). Irrespective of the driving force of the cycle - asymmetric information or voter inexperience - it indicates the absence of checks and balances on politicians common in mature democracies (i.e., separation of powers, free media, active NGOs, etc.) that give voters fuller information and longer-term control over politicians." (ibidem, p. 3, 4 and 5)

Finally, Brender and Drazen (op. cit.) analyze a group of countries at different levels of development to show that voters in developed countries are fiscal conservatives, rewarding reduced deficit both throughout the term and in the pre-vote year. In less-developed countries, on the other hand, there is no statistically significant relationship between deficit and reelection; which does not allow us to reject the hypothesis that there is a preference for fiscal expansionism in such countries. When countries are divided into new and old democracies, the results show that voters in older democracies are fiscal conservatives, but no statistically significant correlation is found for young democracies. This is possibly an indication of a learning 
process by voters, who, in the course of many administrations and elections, might understand the importance of long-term fiscal balance and become less susceptible to pre-vote maneuvers on the part of politicians.

\section{Municipal Elections in Brazil: Institutional Characteristics}

Brazil is a federation with three levels of government: Federal Government (Union), 26 state governments, 1 Federal District (national capital), and 5,506 municipalities in the year 2000 (by 2007, the number had risen to 5,562). The 1988 Federal Constitution guarantees municipalities their status as federation members (not subordinated, therefore, to the states or the Union), with local elections every four years for two branches (Executive and Legislative), local tax jurisdiction and constitutional entitlement to inter-governmental transfers.

Brazil provides an appropriate situation for the intended econometric study. Firstly, such a large number of municipalities supply a lot of information. ${ }^{4}$ In addition, certain institutional characteristics make the study easier: municipal elections (for mayor and councilors) for four-year terms are held on the same day in every municipality. The timing of the election is therefore exogenous and does not depend on incumbent performance, unlike voting systems where elections can be convened at any time. The law prohibited reelection for executive positions until 1996 (president of the Republic, governors and mayors). A constitutional amendment was passed in June $1997^{5}$ allowing an additional term for these positions.

As a result, every mayor elected in November 1996 was eligible to run for reelection in November 2000. It is important to point out that mayors already knew that they would be able to attempt reelection right from the very beginning of their terms, and could therefore design their administration strategies with this in mind. ${ }^{6}$ Furthermore, the timing of Brazilian municipal elections is different from that of state and federal elections. The latter two are held simultaneously, two years into the intervening period between municipal elections. This means that mayors have the following choices available to them at the end of their terms:

1) Give up their political career;

2) Run for councilor (a municipal role of lesser importance);

4 Brender (2003), for example, relied on little more than 100 observations to analyze the Israeli case, while we worked with 2,732 observations.

5 Constitutional Amendment No. 16, dated June 5th, 1997.

6 See Schlesinger (1966) on vertical or horizontal political career advancement. 
3) Run for reelection;

4) Spend two years without a mandate while awaiting the opportunity to run for a different position at the state or federal level.

For the purposes of this article, choice \# 4 will be deemed subordinated to choice \#3 and, therefore, disregarded. This is because incumbent mayors can run for a different office at any time. For a politician who is aiming to advance his or her career by attempting state or federal office, the best choice is to run for reelection as mayor (choice \#3) and, two years later, use their status as mayor (media exposure, administrative accomplishments, public funds) to launch a more ambitious candidature with higher stakes involved. Spending two years in limbo to then return to the political scene in pursuit of a higher position is not common practice in Brazilian politics.

Choice \#2, in turn, is practically equivalent to giving up the political career (choice $\# 1$ ), due to the great difference in status between the office of mayor and that of councilor. This choice, besides being statistically irrelevant (only 10 cases in a universe of over five thousand observations), indicates that the individual has a very poor chance of reelection and advancement as a politician.

Therefore, only choices \#1 and \#3 - whether to run for reelection or not - are relevant. Our hypothesis is that politicians wish to be reelected.

\section{The Model and the Data}

\subsection{The Model}

The probability of success when searching for a second term may be modeled as a probit binary choice with selection of the type:

$$
\begin{aligned}
& R E E L_{i}^{*}=\alpha^{\prime} z_{i}+\eta_{i} \\
& R E E L_{i}=1 \text { if } R E E L_{i}^{*}>0 \text { or } R E E L_{t}=0 \text { if } R E E L_{t}^{*} \leq 0
\end{aligned}
$$

The $\operatorname{REEL}_{i}^{*}$ variable shows the probability of mayor being reelected, considering all control terms contained in vector $\mathrm{z}_{\mathrm{i}}$; where $\mathrm{i}$ is the observation unit (i.e., the municipality and its mayor). Nevertheless, the value of REEL* is not observed. One can 
only observe whether the mayor is reelected or not. It obliges us to work with the binary variable $R E E L_{i}$, which indicates whether the mayor was reelected $\left(R E E L_{i}\right.$ $=1$ ) or not $\left(\right.$ REEL $\left._{\mathrm{i}}=0\right)$. Assuming that $\eta_{\mathrm{i}}$ has a standard normal distribution, with mean 0 and variance 1 , the probability of the mayor being reelected is given by the normal accumulated density function $£($.$) .$

Given that Mainwaring (1999) considers parties to be weak, with poor partisan discipline (politicians can freely switch parties in the course of their terms, and often do), and there are no clear ideological distinctions between them, we do not consider the reelection of parties. As there is information available on the permanence of individuals in power, we will work with this more accurate concept.

Despite the countless benefits of working with individuals in a personal voting system with weak party discipline, ${ }^{7}$ a constraint arises: the effects of reelection cannot be analyzed in the long run by means of panel analysis. Because the law only allows reelection once for each mayor, we were unable to build a panel to observe the ballot performance of a given politician over several elections: each politician will be present, at most, in two successive elections for mayor, which generates a single reelection observation. As a result, we can only perform a cross-section analysis, which subjects the results to the political and economic circumstances in force at the time of the cross-section observation ("time effect"). We could also not isolate the "fixed effect" of municipalities, using a fixed effect panel data model. Having only a cross-section database we use a large set of control variables to isolate the specific features of municipalities and the personal traits of mayors from the analysis.

In order to define the main fiscal variables, we followed the pattern suggested by Brender and Drazen (op.cit.), defining fiscal expansion or contraction by comparing the average of the variable in the second half of the term with its average during the first half. Given that mayors are elected for four-year terms, the average of the last two years is compared with the average of the first two. To check results for robustness, we used alternative definitions.

The set of control variables comprises the geographical, social and economic features of municipalities and the personal features of mayors. The idea is to control for the many specific characteristics (for instance, the level of economic and social development) that may influence voter behavior and the electoral result. Following Brender (op. cit.), Drazen and Eslava (op. cit.), Brender and Drazen (op. cit.), and Veiga and Veiga (op. cit.), we control the percentage of votes the mayor obtained in his or her former election (Votes ${ }_{96}$ ) as a means of controlling for popularity, perso-

7 See Brazil's classification in Carey and Shugart (1995). 
nal characteristics or "political capital". Other control variables are the geographic area of each municipality (variable Area), number of inhabitants in 2000 (variable Population $_{00}$ ), population growth in the period between the 1991 and the 2000 census (variable Population Growth (0091 $_{1}$ ), a dummy variable with a value equal to 1 for municipalities that belong to a metropolitan region and zero otherwise (variable Metropolitan Region), dummy variables (each region has a dummy with a value equal to 1 and zero, otherwise) for four Brazilian regions: North, Northeast, Midwest, and South; a dummy variable with its value equal to 1 for municipalities that are state capitals and zero otherwise (variable State Capital), percentage of the population that lives in urban areas of the municipality (variable Urban Population), the municipal population as a percentage of the total state population (variable $\%$ of State Population) and a dummy variable with its value equal to 1 if the 2000 election is the first election in a recently created municipality and zero otherwise (variable New Municipality).

It is worthwhile explaining the importance of the variable New Municipality. Municipalities are able to manipulate fund distribution criteria in such a manner as to secure additional resources from the two main sources of transfer revenues. This is done by creating new municipalities from the subdivision of existing ones. According to IBGE data, 50 percent of the country's municipalities have fewer than 10 thousand inhabitants. This is not an exogenous factor arising simply from socioeconomic and geographic conditions. The 1988 Constitution established sharing criteria for the Municipal Participation Fund (the main source of federal transfers) that are strongly biased in favor of municipalities with up to 10,163 inhabitants. As a result, a wave of municipalities was created. Larger municipalities began to subdivide in an effort to secure additional federal funds. In 1980 Brazil had 3,991 municipalities. The number rose to 4,974 in 1993 and 5,567 in 2004. ${ }^{8}$ Countless municipalities were created simply to receive transfers without having the minimum traits of local identity, community structure or the potential for fiscal selfsustainability that might characterize such places as independent towns.

The second largest item of transfers to municipalities also induces municipality multiplication, but for different reasons. The transfer of $25 \%$ of the states' VAT (ICMS) to municipalities is divided according to the destination principle: transfers are made to the municipality where the state-tax was collected. Given that ICMS is partly collected at source, the state government generates high revenues from this tax in municipalities that are home to large commercial or industrial establishments. As a result, such municipalities are entitled to hefty transfers. This has

8 Instituto Brasileiro de Geografia e Estatística [Brazilian Institute of Geography and Statistics] (IBGE). For a detailed analysis of the municipality creation process, see Shikida (1998) 
encouraged industrial districts to seek emancipation, thus becoming autonomous municipalities in order to internalize such transfers.

Considering that Heckman (1979) argues that the choice of running for reelection should not be exogenous but determined by pre-established conditions and that if this rule is ignored, individuals with these conditions are compared to individuals without them, we decided to control the possibility of selection. Heckman (ibidem) developed a methodology for dealing with this. Our target is to adapt this model before (equation [1]) by considering that the pre-established condition which individuals share for running for reelection is their age. This aspect is even included in our controls, where we have included a dummy for individuals over 70 (variable elderly), because they are less capable of running for reelection (candidate) than younger individuals:

$$
\begin{aligned}
& C A N D_{i}^{*}=\beta^{\prime} x_{i}+\varepsilon_{i} \\
& C A N D_{i}=1 \text { if } C A N D_{i}^{*}>0 \text { or } C A N D_{t}=0 \text { if } C A N D_{t}^{*} \leq 0
\end{aligned}
$$

The CANDi* variable shows the mayor's probability of being a candidate in terms of the control and explanatory variables, all of them contained in vector $x_{i}$, where $i$ is the observation unit (i.e., the municipality and its mayor). Nevertheless, the value of $C A N D^{*}$ is not observed. We can only observe if the mayor has decided to be a candidate or not. It obliges us to work with the binary variable $C A N D_{i}$, which indicates whether the mayor was a candidate $\left(C A N D_{i}=1\right)$ or not $\left(C A N D_{i}=0\right)$. Assuming that $\varepsilon_{i}$ has a standard normal distribution, with mean 0 and variance 1 , the probability of the mayor being a candidate is given by the normal accumulated density function $\Phi($.$) .$

One can only estimate the reelection equation (i.e., equation [1]) in those cases in which the mayor was a candidate $\left(C A N D_{i}=1\right)$. In this subset of mayor-candidates, it is assumed that $\eta_{\mathrm{i}}$ and $\varepsilon_{\mathrm{i}}$ have normal bivariate distribution with mean 0 and variance 1 , with a correlation $\rho$ among the errors of the two equations:

$$
[\eta \mathrm{i}, \varepsilon \mathrm{i}] \sim \mathrm{N} 2[0,0,1,1, p \eta \varepsilon]
$$

It is expected that $\rho>0$, in other words, the same variables considered in the model that increase (decrease) candidature probability would also increase (decrease) reelection chances. If $\rho=0$ then there is no selection bias and the reelection and candidature equations are independent, making estimation of the selection model unnecessary. In this case, it would be possible to estimate only the reelection equation (i.e., a simple Probit model). 


\subsection{Data}

In accordance with data from the Tribunal Superior Eleitoral [Superior Electoral Court] (TSE), 43\% of the sampled mayors were reelected. Of the $57 \%$ that did not achieve reelection, 30\% ran, and 27\% did not. Data on the ballot, fiscal policy, socio-economic features and the mayor's personal characteristics were not always available for all municipalities, which reduced our sample. In addition, three mayors ran for state or federal-level offices in 1998 and stayed out of the 2000 race; and 21 mayors died in the course of their first mandate. This left us with 2,732 municipalities, or $49.6 \%$ of the 5,506 municipalities that existed in Brazil in 2000 .

This raises the possibility of sampling bias, given that data unavailability may be caused by a specific type of municipality, such as, for example, those in less developed areas, those with limited administrative capabilities, etc., and those where voter preferences also differ from the average. To assess this possibility, Table 1 provides average figures for some of the municipal characteristics available for all 5,506 municipalities and compares them with the averages obtained from the sample.

Table 1 - Characteristics of Brazilian Municipalities: universe vs. sample (averages)

\begin{tabular}{lrr}
\hline & Universe & Sample \\
\hline State capital & $0.47 \%$ & $0.51 \%$ \\
North Region & $8.2 \%$ & $3.5 \%$ \\
Northeast Region & $32.5 \%$ & $20.8 \%$ \\
Center-West Region & $8.1 \%$ & $8.7 \%$ \\
South Region & $21.0 \%$ & $30.7 \%$ \\
Southeast Region & $30.3 \%$ & $36.3 \%$ \\
Life expectancy at birth (years) & 67.7 & 69.1 \\
Adult literacy rate (\%) & $78.2 \%$ & $81.6 \%$ \\
Gross school attendance rate (\%) & $78.0 \%$ & $78.0 \%$ \\
Per capita income (2000 R\$) & 171 & 194 \\
Longevity index (IDHM-L) & 0.712 & 0.735 \\
Education index (IDHM-E) & 0.781 & 0.804 \\
Income index (IDHM-R) & 0.604 & 0.631 \\
Municipal Human Development Index (IDH-M) & 0.699 & 0.723 \\
Population, 2000 & 30,466 & 32,643 \\
Percentage of population residing in urban area & $59 \%$ & $60 \%$ \\
\hline
\end{tabular}

Source: UNDP. 
Note that municipalities in the Northern and Northeastern regions, the country's poorest and least developed, are under-represented in the sample. On the other hand, municipalities in the more developed areas (South and Southeast) are over-represented. This is reflected in the other statistics: the sample's Human Development Index is higher than that of the universe, as is also the case with income, schooling, life expectancy and education indicators. The sample's average population is also a little higher than that of the universe.

The bias in the estimated coefficients, which may be a result of this sampling bias, does not invalidate the results discussed here. Quite the opposite; it is an indication of robustness, because, as we shall see further on, municipalities in the North and Northeast, as well as those with lower schooling are those where voters are most likely to support expenditure expansionism. Therefore, if we obtain evidence that the sampled voters support expenditure increases, the same goes for the whole electorate. Appendix I provides a detailed description of the main fiscal variables, control variables, their sources and the descriptive statistics.

\section{Estimations and Basic Results}

Table 2 shows our basic results. We show the technique used to estimate in the first line of each column. The six first columns are procedures for finding better estimates, considering the federalism model that exists in Brazil and the result of the log-likelihood statistics.

Considering that there is the possibility of pre-established conditions to someone being a candidate, the last column shows the selection estimate (following the equation [2]) and the Probit-Heckman-VII column shows the Probit result with selection bias corrected. The first line of these two columns also shows the general estimated probability. The values in brackets are the $t$ statistic for the significance test. All of the estimates are based on robust tests (standard deviation with Huber/ White/Sandwich heteroscedasticity correction). Given the large number of variables, we use a darker background to emphasize variables that are significant at least at the $10 \%$ confidence level. 
Table 2 - Probability of mayor's reelection (2000)

\begin{tabular}{|c|c|c|c|c|c|c|c|c|}
\hline $\begin{array}{l}\text { Independent } \\
\text { Variables }\end{array}$ & Probit-I & Probit-II & Probit-III & Probit-IV & Probit-V & Probit-VI & $\begin{array}{l}\text { Probit- } \\
\text { Heckman- } \\
\text { VII } \\
(\mathrm{P}=0.67)\end{array}$ & $\begin{array}{c}\text { Candidate- } \\
\text { Selection- } \\
\text { VIII } \\
(P=0.74)\end{array}$ \\
\hline $\begin{array}{l}\text { Current Fiscal } \\
\text { Result (\%change) }\end{array}$ & $\begin{array}{r}0.0006 \\
(1.03)\end{array}$ & $\begin{array}{r}0.0006 \\
(0.91)\end{array}$ & & & & & & \\
\hline $\begin{array}{l}\text { Tax Revenue } \\
\text { (\%change) }\end{array}$ & & & $\begin{array}{l}0.003 \\
(1.58)\end{array}$ & $\begin{array}{l}0.003 \\
(1.55)\end{array}$ & $\begin{array}{l}0.005 \\
(0.77)\end{array}$ & $\begin{array}{l}0.002^{* * *} \\
(1.60)\end{array}$ & $\begin{array}{l}0.002 \\
(0.80)\end{array}$ & $\begin{array}{l}0.002 \\
(1.27)\end{array}$ \\
\hline $\begin{array}{l}\text { Current Expenditure } \\
(\% \text { change) }\end{array}$ & & & $\begin{array}{l}0.41^{*} \\
(6.07)\end{array}$ & $\begin{array}{r}0.39^{*} \\
(4.61)\end{array}$ & & $\begin{array}{l}0.41^{*} \\
(6.07)\end{array}$ & $\begin{array}{l}0.19^{\star * *} \\
(1.91)\end{array}$ & $\begin{array}{l}0.34^{*} \\
(5.57)\end{array}$ \\
\hline $\begin{array}{l}\text { Current Transfers } \\
\text { (\% change) }\end{array}$ & & & & $\begin{array}{l}0.03 \\
(0.47)\end{array}$ & $\begin{array}{r}0.26^{*} \\
(4.34)\end{array}$ & & & \\
\hline $\begin{array}{l}\text { Debt(difference } \\
\text { in \% of Total } \\
\text { Revenue) }\end{array}$ & $\begin{array}{l}-0.122^{\star *} \\
(-2.19)\end{array}$ & $\begin{array}{c}-0.06 \\
(-1.21)\end{array}$ & $\begin{array}{l}-0.03 \\
(-0.66)\end{array}$ & $\begin{array}{c}-0.03 \\
(-0.63)\end{array}$ & $\begin{array}{l}-0.03 \\
(-0.70)\end{array}$ & $\begin{array}{l}-0.04 \\
(-0.79)\end{array}$ & $\begin{array}{l}-0.15^{\star \star} \\
(-2.40)\end{array}$ & $\begin{array}{l}0.09^{* * *} \\
(1.95)\end{array}$ \\
\hline $\begin{array}{l}\text { Debt } 98(\% \text { of Total } \\
\text { Revenue) }\end{array}$ & $\begin{array}{l}-0.200^{*} \\
(-4.40)\end{array}$ & $\begin{array}{l}-0.08^{\star * *} \\
(-1.77)\end{array}$ & $\begin{array}{c}-0.03 \\
(-0.81)\end{array}$ & $\begin{array}{c}-0.03 \\
(-0.83)\end{array}$ & $\begin{array}{c}-0.07 \\
(-1.54)\end{array}$ & $\begin{array}{l}-0.04 \\
(-0.97)\end{array}$ & $\begin{array}{l}-0.14^{*} \\
(-2.86)\end{array}$ & $\begin{array}{l}0.08^{* *} \\
(2.26)\end{array}$ \\
\hline Bailout & & & & & & $\begin{array}{c}0.05 \\
(1.03)\end{array}$ & $\begin{array}{l}0.08 \\
(1.56)\end{array}$ & $\begin{array}{l}-0.05 \\
(-1.02)\end{array}$ \\
\hline Votes96 & & $\begin{array}{l}0.006^{*} \\
(5.93)\end{array}$ & $\begin{array}{l}0.006^{*} \\
(5.91)\end{array}$ & $\begin{array}{l}0.006^{*} \\
(5.92)\end{array}$ & $\begin{array}{l}0.006^{*} \\
(5.99)\end{array}$ & $\begin{array}{l}0.006^{*} \\
(5.91)\end{array}$ & $\begin{array}{l}0.01^{*} \\
(6.94)\end{array}$ & $\begin{array}{l}-0.002^{* *} \\
(-2.74)\end{array}$ \\
\hline Literacy (adults) & & $\begin{array}{l}-0.34^{\star \star} \\
(-2.07)\end{array}$ & $\begin{array}{c}-0.21 \\
(-1.28)\end{array}$ & $\begin{array}{c}-0.21 \\
(-1.28)\end{array}$ & $\begin{array}{l}-0.29^{\star * *} \\
(-1.71)\end{array}$ & $\begin{array}{l}-0.23 \\
(-1.35)\end{array}$ & $\begin{array}{l}-0.01 \\
(-0.08)\end{array}$ & $\begin{array}{l}-0.27^{\star *} \\
(-1.75)\end{array}$ \\
\hline New Municipality & & $\begin{array}{l}0.23^{*} \\
(6.15)\end{array}$ & $\begin{array}{r}0.18^{*} \\
(4.68)\end{array}$ & $\begin{array}{r}0.18^{*} \\
(4.69)\end{array}$ & $\begin{array}{r}0.22^{*} \\
(5.69)\end{array}$ & $\begin{array}{l}0.18^{*} \\
(4.65)\end{array}$ & $\begin{array}{l}0.07^{\star \star *} \\
(1.63)\end{array}$ & $\begin{array}{l}0.14^{*} \\
(5.32)\end{array}$ \\
\hline Area $(\mathrm{km} 2)$ & & $\begin{array}{c}3.27 e-06 \\
(0.62)\end{array}$ & $\begin{array}{c}4.18 \mathrm{e}-07 \\
(0.08)\end{array}$ & $\begin{array}{l}4.40 \mathrm{e}-07 \\
(0.08)\end{array}$ & $\begin{array}{c}2.31 e-06 \\
(0.44)\end{array}$ & $\begin{array}{l}1.16 \mathrm{e}-07 \\
(0.02)\end{array}$ & $\begin{array}{c}2.93 e-07 \\
(0.05)\end{array}$ & $\begin{array}{r}-1.19 e-6 \\
(-0.27)\end{array}$ \\
\hline Population00 & & $\begin{array}{l}1.57 e-08 \\
(0.28)\end{array}$ & $\begin{array}{c}6.76 \mathrm{e}-09 \\
(0.12)\end{array}$ & $\begin{array}{c}5.81 \mathrm{e}-09 \\
(0.11)\end{array}$ & $\begin{array}{l}4.89 \mathrm{e}-09 \\
(0.09)\end{array}$ & $\begin{array}{l}1.18 \mathrm{e}-09 \\
(0.02)\end{array}$ & $\begin{array}{l}5.05 e-07^{\star *} \\
(2.21)\end{array}$ & $\begin{array}{c}-3.04 e-08 \\
(-0.71)\end{array}$ \\
\hline $\begin{array}{l}\text { Population } \\
\text { Growth0091 }\end{array}$ & & $\begin{array}{l}0.99^{\star \star *} \\
(1.71)\end{array}$ & $\begin{array}{l}0.28 \\
(0.45)\end{array}$ & $\begin{array}{l}0.24 \\
(0.39)\end{array}$ & $\begin{array}{l}0.43 \\
(0.72)\end{array}$ & $\begin{array}{l}0.29 \\
(0.46)\end{array}$ & $\begin{array}{l}-0.02 \\
(-0.03)\end{array}$ & $\begin{array}{l}0.83^{\star \star \star} \\
(1.61)\end{array}$ \\
\hline $\begin{array}{l}\% \text { of State } \\
\text { Population }\end{array}$ & & $\begin{array}{l}-0.15 \\
(-0.27)\end{array}$ & $\begin{array}{l}-0.06 \\
(-0.12)\end{array}$ & $\begin{array}{c}-0.08 \\
(-0.14)\end{array}$ & $\begin{array}{l}-0.19 \\
(-0.35)\end{array}$ & $\begin{array}{l}-0.07 \\
(-0.13)\end{array}$ & $\begin{array}{l}-0.54 \\
(-0.91)\end{array}$ & $\begin{array}{c}-0.08 \\
(-0.18)\end{array}$ \\
\hline $\begin{array}{l}\text { Urban Population } \\
(\%)\end{array}$ & & $\begin{array}{c}0.07 \\
(1.41)\end{array}$ & $\begin{array}{l}0.08^{* * *} \\
(1.63)\end{array}$ & $\begin{array}{l}0.08^{\star \star \star} \\
(1.61)\end{array}$ & $\begin{array}{l}0.07 \\
(1.40)\end{array}$ & $\begin{array}{c}0.08 \\
(1.56)\end{array}$ & $\begin{array}{l}-0.11^{* * *} \\
(-1.83)\end{array}$ & $\begin{array}{l}0.20^{*} \\
(4.26)\end{array}$ \\
\hline Metropolitan Region & & $\begin{array}{l}0.07^{* *} \\
(2.05)\end{array}$ & $\begin{array}{l}0.07^{\star *} \\
(2.00)\end{array}$ & $\begin{array}{l}0.08^{* *} \\
(1.98)\end{array}$ & $\begin{array}{l}0.06^{* * *} \\
(1.89)\end{array}$ & $\begin{array}{l}0.07^{\star \star} \\
(1.96)\end{array}$ & $\begin{array}{l}0.05 \\
(1.33) \\
\end{array}$ & $\begin{array}{l}0.01 \\
(0.47)\end{array}$ \\
\hline
\end{tabular}


(continuation)

\begin{tabular}{|c|c|c|c|c|c|c|c|c|}
\hline $\begin{array}{l}\text { Independent } \\
\text { Variables }\end{array}$ & Probit-I & Probit-II & Probit-III & Probit-IV & Probit-V & Probit-VI & $\begin{array}{c}\text { Probit- } \\
\text { Heckman- } \\
\text { VII } \\
(\mathrm{P}=0.67)\end{array}$ & $\begin{array}{c}\text { Candidate- } \\
\text { Selection- } \\
\text { VIII } \\
(\mathrm{P}=0.74)\end{array}$ \\
\hline State Capital & & $\begin{array}{c}0.15 \\
(0.74) \\
\end{array}$ & $\begin{array}{c}0.187 \\
(0.89)\end{array}$ & $\begin{array}{c}0.19 \\
(0.92) \\
\end{array}$ & $\begin{array}{c}0.22 \\
(1.10) \\
\end{array}$ & $\begin{array}{c}0.18 \\
(0.90) \\
\end{array}$ & $\begin{array}{c}-0.09 \\
(-0.29)\end{array}$ & $\begin{array}{c}-0.006 \\
(-0.04) \\
\end{array}$ \\
\hline North & & $\begin{array}{l}0.01 \\
(0.24)\end{array}$ & $\begin{array}{l}0.02 \\
(0.37)\end{array}$ & $\begin{array}{l}0.19 \\
(0.35)\end{array}$ & $\begin{array}{l}-0.01 \\
(-0.16)\end{array}$ & $\begin{array}{l}0.02 \\
(0.40)\end{array}$ & $\begin{array}{l}0.01 \\
(0.31)\end{array}$ & $\begin{array}{l}0.003 \\
(0.07)\end{array}$ \\
\hline Northeast & & $\begin{array}{l}0.15^{\star} \\
(3.80)\end{array}$ & $\begin{array}{l}0.14^{*} \\
(3.56)\end{array}$ & $\begin{array}{l}0.14^{*} \\
(3.50)\end{array}$ & $\begin{array}{l}0.13^{*} \\
(3.33)\end{array}$ & $\begin{array}{l}0.14^{*} \\
(3.54)\end{array}$ & $\begin{array}{l}0.14^{*} \\
(3.28)\end{array}$ & $\begin{array}{l}0.009 \\
(0.24)\end{array}$ \\
\hline Midwest & & $\begin{array}{l}-0.08^{\star *} \\
(-2.08)\end{array}$ & $\begin{array}{l}-0.08^{\star *} \\
(-2.19)\end{array}$ & $\begin{array}{l}0.03 \\
0.03)\end{array}$ & $\begin{array}{l}-0.07^{\star \star} \\
(-2.02)\end{array}$ & $\begin{array}{l}-0.08^{\star *} \\
(-2.16)\end{array}$ & $\begin{array}{l}0.05 \\
(1.14)\end{array}$ & $\begin{array}{l}-0.18^{*} \\
(-4.74)\end{array}$ \\
\hline South & & $\begin{array}{l}0.02 \\
(0.94)\end{array}$ & $\begin{array}{l}0.04 \\
(1.58)\end{array}$ & $\begin{array}{l}0.04 \\
(1.58)\end{array}$ & $\begin{array}{l}0.03 \\
(1.29)\end{array}$ & $\begin{array}{l}0.04^{* * *} \\
(1.64)\end{array}$ & $\begin{array}{l}0.07^{\star \star} \\
(2.49)\end{array}$ & $\begin{array}{l}-0.01 \\
(-0.55)\end{array}$ \\
\hline Elderly & & & & & & & & $\begin{array}{l}-0.37^{*} \\
(-6.31)\end{array}$ \\
\hline Observations & 2732 & 2732 & 2732 & 2732 & 2732 & 2732 & 2732 & \\
\hline $\begin{array}{l}\text { Censored Observa- } \\
\text { tion }\end{array}$ & & & & & & & 740 & \\
\hline $\begin{array}{l}\text { Uncensored Obser- } \\
\text { vations }\end{array}$ & & & & & & & 1992 & \\
\hline Log-likelihood & -1850.6 & -1759.11 & -1737.79 & -1737.68 & -1749.04 & -1737.06 & -2720.06 & \\
\hline Rho & & & & & & & -0.49 & \\
\hline $\begin{array}{l}\text { Prob. Indep of } \\
\text { Equations }\end{array}$ & & & & & & & 0.24 & \\
\hline Pseudo R2 & 0.007 & 0.05 & 0.06 & 0.06 & 0.06 & 0.06 & & \\
\hline Observed P & 0.426 & 0.426 & 0.426 & 0.426 & 0.426 & 0.426 & & \\
\hline Predicted P & 0.426 & 0.424 & 0.424 & 0.424 & 0.424 & 0.424 & & \\
\hline
\end{tabular}

Notes: ${ }^{* * *} 10 \%,{ }^{* *} 5 \%,{ }^{*} 1 \%$. For each independent variable we report $(\mathrm{dF} / \mathrm{dx})$, i.e., the marginal change in the probability of success for the average values of the other independent variables. In parentheses, we report the t-statistics based on robust, heteroscedastic-consistent standard errors (Huber/White/Sandwich).

In the Probit-I column we included three fiscal variables: the change in current surplus [Current Fiscal Result (\%change)], the change in the debt/revenue ratio over the term [Debt (difference in \% of Total Revenue)], and the debt/revenue ratio at the beginning of the term [Debt 98 (\% of Total Revenue)]. The first results seem contradictory: while the impact of the current surplus is non-significant, the increase in indebtedness over the term and high debt at the beginning of the term seem to work against reelection (which could be interpreted as a sign of voters' fiscal con- 
servativeness). Taking some alternative fiscal variables, we can see that if we use the Current Fiscal Result (difference) in place of the Current Fiscal Result (\%change) there is no change in the qualitative results (non-reported results). However, when we use Debt (\% change) in place of Debt (difference in \% of Total Revenue), the coefficient for the variation in the debt/revenue ratio changes its sign: now it gives a positive sign, with $7 \%$ significance (non-reported result).

The inclusion of control variables in the Probit-II column changes the picture and generates results that are robust to changes in variable definitions. The marked reduction in the log-likelihood statistic and the increase of pseudo $-\mathrm{R}^{2}$, presented at the bottom of the table, show that including the control variables increased the estimation accuracy. The coefficients of the interest variables were altered: the change in debt over the term [Debt (difference in \% of Total Revenue)] is no longer significant. The debt at the beginning of the term [Debt 98 (\% of Total Revenue)] is significant at the 10\% level only and the absolute value of the coefficient has decreased a lot, while current surplus has remained non-significant. Moreover, the qualitative results are robust to changes in variable definitions: Current Fiscal Result (difference) in place of Current Fiscal Result (\% change) and Debt (\% change) in place of Debt (difference in $\%$ of Total Revenue). ${ }^{9}$

The Probit-III column in Table 2 analyzes fiscal results, splitting the change in fiscal surplus into changes in tax revenue [Tax Revenue (\%change)] and changes in current expenditure [Current Expenditure (\%change)]. Both variables are defined to represent change during the term, with a definition similar to Current Fiscal Result (\%change). Increased current expenditure has a strong positive effect on the probability of reelection. Graph 1 illustrates this effect: taking the other variables at their means and considering an "old municipality", if Current Expenditure (\%change) is $10 \%$, the probability of reelection is about 34\%; if Current Expenditure (\%change) increases to $40 \%$, reelection probability jumps to $45 \%$.

9 The result is also robust to other changes in variables. For instance, the replacement of the variable Current Fiscal Result for Total Fiscal Result (Total fiscal result $=$ current + capital): the "difference" or "\% change" form. See Appendix I for variable definitions. 


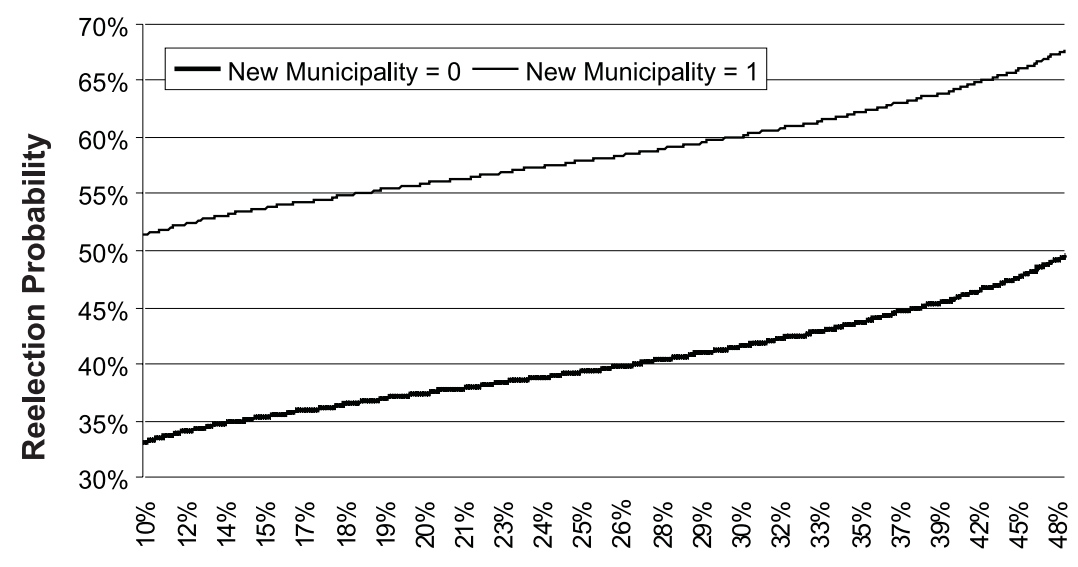

Current Expenditures (\%change)

\section{Graph 1 - Probability of Mayor's Reelection as a Function o Current Expenditure Variation (2000)}

In contrast, tax revenue, debt at the beginning of the term and its change over the term are not significant. Once more, qualitative results are robust to changes in variable definitions. ${ }^{10}$

Let us then explore the data somewhat more in order to analyze the possible causes of Brazilian voters' preference for fiscal profligacy on the part of their mayors. To check the impact of current transfers on reelection, the Probit-IV column in Table 2 includes the change in these transfers [Current Transfers (\%change)] as an independent variable.

It is important to point out that fiscal transfers from the Federal Government and from state governments are a central part of the Brazilian federal model. They represent the major source of funds for the vast majority of municipalities. According to the Government Finance Statistics Yearbook, IMF, 2003, own tax revenues represent on average only 24\% of the total revenue for Brazilian municipalities, the other $76 \%$ being represented by transfers. Only in the United Kingdom (with a unitary government system and local governments with little autonomy and few attributions) do current transfers amount to such a high share of local government revenues. Municipalities in Latin American neighbors such as Mexico, Chile and

10 The replacement of variables Current Expenditure (\% change), Tax Revenue (\%change) and Debt (difference in \% of Total Revenue) for alternative specifications; Total Expenditure (\%change), Total Expenditure (mean $98-00 / 97)_{\text {), Total Expenditure }}$ (mean of yearly change), Current Expenditure (mean 98-00/97), $_{\text {, Current Expenditure }}$ (mean of yearly change), Tax Revenue (mean 98-00/97), Debt(\% change) do not change the qualitative results. See Appendix I for variable definitions. 
Colombia are far less dependent on transfers. Federations with large territories and broad social or economic diversity, like Brazil (Russia, Canada, Australia and the USA) also have less transfer-dependent local governments. Analyzing the case of Israel, Brender (op. cit.) argues that $60 \%$ of its local government revenues are generated in the municipality itself, while in Brazil local tax revenues represent no more than $20 \%$ of the total. This large and atypical volume of transfers that Brazilian municipal governments receive led Shah (1994, p. 42) to state "municipal governments in Brazil (...) should be the envy of all governments in developing, as well industrial countries".

Despite this huge importance in municipal revenue, when we include the variable [Current Transfers (\%change)] in the model (Table 2, column Probit IV) the coefficient is not statistically significant. But change in transfers is strongly correlated with change in spending [Current Expenditure (\%change)]. ${ }^{11}$ When we estimate the model by retaining transfers and removing current expenditure (Table 2, column Probit-V), current transfers have an important impact on the probability of reelection.

How should we interpret the results presented above? Which kind of incentive induces mayors to expand expenditure and makes voters reward such behavior? Rodden (2002) presents a model that provides a good explanation for the mechanisms that lead to the "soft budget constraint" on Brazilian municipalities. According to this author, in a federation, sub-national governments tend to behave as "freeriders" on the benefits created by fiscal stability. Central government, which is politically responsible for macroeconomic equilibrium, has incentives to create mechanisms to impose financial discipline on states and municipalities. But it may not have the political power or instruments to do so. We must, therefore, check for factors that determine central government's ability to subject other government levels to financial discipline.

First, there is the issue of the influence of local powers over national decisions. Because federal congress members are elected on a local basis they tend to uphold the interests of their electoral districts in the federal parliament, bargaining for additional financial support. This clearly weakens central government's commitment not to offer bailouts.

11 There is high correlation between variables $(0,67)$. It is also important to point out that although the main transfers to municipalities are not earmarked for any type of expenditure by local governments, some health and education-related earmarked funds induce this positive correlation. About 15\% of the two main items of transfers to municipalities, FPM and ICMS, which will be discussed below, are set aside for education. In the health area, some transfers are required to be used in the Unified Health System. 
In Brazil, this influence is highly significant, given that the electoral system induces the establishment of geographically-limited voter bases, turning a large proportion of representatives into advocates of municipal and state interests before the National Congress (MAINWARING, op. cit., SAMUELS, 2003).

Secondly, heterogeneity between the various municipalities can also weaken the non-bailout commitment. In the presence of very large municipalities, the bankruptcy of which can create negative externalities for the remainder of the country ("too big to fail"), there will be an incentive for financial rescue. On the other hand, there are also municipalities that are "too small to fail", in other words, those that support bailouts for large municipalities in exchange for equal treatment and that also require financial assistance or additional transfers. Since the fiscal cost of this help to small municipalities is inexpressive vis-à-vis the overall taxpayer population, there is an opportunity for bargaining and cooperative action between the "too big to fail" and the "too small to fail". Furthermore, because federal constitutions tend to deviate from the one man one vote principle, small local governments tend to be over-represented, which increases the bargaining power of small municipalities.

Once again, Brazil fits this description perfectly: the least populated states and municipalities are over-represented in Congress and great size disparity exists between municipalities. While the smallest (Borá, in the State of São Paulo) has less than one thousand inhabitants, the largest, São Paulo, also in the State of São Paulo, is a megalopolis of over ten million.

According to IBGE data, 50\% of all Brazilian municipalities in the year 2000 had fewer than 10 thousand inhabitants. These nearly three thousand municipalities greatly benefit from the federal and state transfer sharing system. Even taking into account the economies of scale of larger municipalities, the transfer system is clearly biased in favor of small-population municipalities. The criteria that create this transfer bias are set out in the Federal Constitution. The privilege continues not only because small municipalities are over-represented in Congress, but also because the bias serves as compensation for the frequent federal bailouts that mainly serve the larger and more populated municipalities. This, then, is the cooperative interplay between the "too small to fail" and the "too big to fail": small ones benefit from the transfer system and large ones from debt bailouts. In the course of the 1980s and 1990s, several state and municipal debt bailouts took place. To give an idea of their size, in April 2007 the Union's credit against states and municipalities from debt refinancing stood at 15\% of GDP, of which 13\% came from states and 2\% from municipalities. ${ }^{12}$ The latest round of bailouts began in 1997, when the Union

12 Secretaria do Tesouro Nacional [Treasury Department]. 
absorbed state debts. In 1999 a similar program was passed for municipalities. ${ }^{13}$ One hundred and eighty municipalities benefited from this. The beneficiary municipalities are, in fact, the most populated. Municipalities of up to 20 thousand inhabitants are under-represented; the reverse applies to the more populous ones. For example, municipalities between 50 and 100 thousand inhabitants represent 6\% of all municipalities in Brazil, and 19\% of the total number of bailout beneficiaries. It is worth pointing out that refinancing the debt of the Municipality of São Paulo, the country's largest (a typical case of "too big to fail”), accounted for $70 \%$ of the total funds used by the Federal Government in support of municipalities. ${ }^{14}$

Also according to Rodden (op. cit.), another important factor in central government's ability to successfully enforce hard budget constraint on sub-national governments is the presence of (effective) legal constraints against state and municipality indebtedness. With limited access to the credit market, the power that municipalities have to run deficits is limited, thus nipping in the bud mayors' intentions to incur debt and thereby reducing their ability to press central government for financial aid.

The Brazilian Constitution lays down that it is the Senate's duty to impose limits on sub-national indebtedness. But the very significant presence of state and municipal interests in the Senate leads to repeated instances of flexibilization and exception, which make indebtedness limits non-binding. ${ }^{15}$ An index of sub-national borrowing autonomy, computed by Stein (1999), ranks Brazil as the country with the second greatest autonomy for sub-national indebtedness in Latin-America, second only to Argentina. This opens the door to an indebtedness today that will become a bailout in the future.

We must also determine, as Brender (op. cit.) proposes, how voters react to the behavior of a mayor who leads the local treasury into bankruptcy to force a federal or state rescue package. This probably depends on the cost to voters. If the mere threat of financial hardship is enough to allow municipalities to get financial support from the Union or states (that is, if resistance to additional or emergency fund injections is low), municipal services will not stop due to a lack of materials or because of personnel strikes. Voters who are not affected by a mayor's fiscal recklessness will tend to support, or at least not mind, expansionist management.

13 These programs attempted to couple the bailout with the states' and municipalities' commitment to fiscal adjustment that, if not complied with, would lead to credible financial sanctions. The program has been able to induce an effective fiscal adjustment among state governments, but from its inception it has been subject to attack from sub-national governments exerting pressure for looser adjustment targets. It is unclear if these stricter budget constraints will prevail in the coming years.

14 Secretaria do Tesouro Nacional.

15 Mendes (1999) analyzes this point. 
This seems to be the case in Brazil: there are no recorded cases of services being suspended due to insolvency. In general, state governments intervene by providing aid in the areas affected by lack of funds. At the federal level, although no bargaining with small or mid-sized municipalities exists to cover deficits or renegotiate debts automatically, all that is needed is for a "too big to fail" municipality (or a group of smaller ones with significant joint political weight) to fall on hard times for negotiations with central government to begin. In times of financial stress and political pressure, federal aid has always come fast, through emergency loans extended by the Federal Treasury, federal banks and even by the Central Bank, followed by renegotiation and absorption of all the debt by the Federal Treasury.

As a result, voters tend not to make a direct connection between fiscal recklessness on the part of a mayor and suspended or deteriorated municipal services. ${ }^{16}$

To better illustrate this point, Table 2 includes an estimation shown in the ProbitVI column that contains a dummy for municipalities that benefited from the 1999 bailout (Bailout). The coefficient is not significant. It shows that voters do not punish mayors who resort to federal help. Since this help did not impose any costs on the municipality and did not lead to a reduction in public services, voters are not annoyed by the fact that their mayor went to the country's capital to beg for money. Although the marginal difference on log-likelihood is little among the other estimates, this result is our choice.

Let us now analyze the control variables. As a means of controlling for popularity, personal characteristics or "political capital", the percentage of votes the mayor obtained in his or her former election (Votes 96 ) has a strong impact on their probability of reelection. ${ }^{17}$

The coefficient of the variable New Municipality indicates that voters tend to support emancipation movements that generate fiscal benefits, as this increases the local availability of funds at the expense of the remainder of the federation. ${ }^{18} \mathrm{In}$ general, the first mayor of a new city is one of the leaders of the previous emancipationist movement. The coefficient of the dummy for new municipalities (New

16 It must also be kept in mind that the main public health and education programs are run jointly and cooperatively at the three government levels. As a result, voters (particularly those who are educationally low achievers) are unable to clearly determine whether responsibility for the collapse in services lies with the President of the Republic, the State Governor or the Municipal Mayor.

17 When Votes $_{96}$ changes from $40 \%$ to $60 \%$, the reelection probability increases more than 10 percentage points.

18 Tomio (2005) shows, for example, that in the State of Rio Grande do Sul, in 263 referendums on the emancipation of municipalities, voters opposed secession in only 8 cases and supported it in 255 . 
Municipality) is significant and indicates an increase of 18 percentage points in the probability of the mayor's reelection (the strongest correlation). Another dummy variable shows that the probability of reelection in metropolitan municipalities (Metropolitan Region 00 ) is 7 percentage points above the mean. With regard to regional dummies, we can see that there are more chances of mayors being reelected in the northeast (Northeast region) and south region (South region) than in the southeast region ( $14 \%$ and $4 \%$ respectively).

Exploring the possibility of a selection bias, we estimated the equation reported in the last two columns of Table 2. We hypothesized that age would be an important variable in the mayor's decision about candidacy for reelection. As they get older all workers think about retirement. In fact, the selection equation (last column) shows that mayors over 70 years old have a candidacy probability that is 37 percentage points lower than the mean probability (which is $73 \%$ ). But the main information in this last estimation is that the reelection equation is independent of the candidacy equation (the hypothesis of $\rho \neq 0$ is rejected). Therefore our simple Probit-VI estimations are consistent.

Turning our attention to the main variables (the fiscal variables), we can see that total revenue [Tax revenue (\%change)] increases the chance of a mayor being reelected by $0.02 \%$ (almost zero and with significance only at the $10 \%$ level). In contrast, an increase in expenditure over the term in office [Current Expenditure (\%change)] significantly increases the probability of the mayor's reelection (41\%). Therefore, the fiscal impact is very important for voters. Considering this result, it is possible to reject the hypothesis found in literature:

HYPOTHESIS 1 - voters are fiscal conservatives: expanded deficit, debt or municipal spending has a negative effect on the chances of reelection.

The results show that voters like municipal spending. The influence of the fiscal federalism model appears to be a determinant of this difference in the case of Brazil, considering that the vast majority of municipalities live from transfers. As was mentioned by Brender (op. cit.) and Akhmedov and Zhurasvskaya (op. cit.), the influence of institutions affects the preference of voters.

\section{Dependence on Schooling}

The notion that voters might be fiscal conservatives is firmly rooted in the concepts of voter rationality and information. Rational, well-informed voters will not admit that an incumbent should overspend, because they realize that this will eventu- 
ally lead to financial crisis or increased taxation. However, rational voters (aware of their preferences and voting accordingly) may lack sufficient information to decide on how to vote. This is the basis of the arguments made by Rogoff (1990) and Rogoff and Sibert (1988), in whose models voters - unable to observe the incumbent's effective competence - look for signs that are indicative of competence. Lack of information for voters can also allow incumbents to prioritize maximizing their own utility function (rather than that of the median voter), by increasing public spending, either to divert funds (STRUMPF, 1988), or gain political power (NISKANEN, 1971). When transfers represent the lion's share of municipal revenues, as is the case of Brazil, the information on public finance that is available to voters is reduced, as is discussed in literature on the flypaper effect: ${ }^{19}$ Voters are better equipped to estimate local tax revenues (being familiar with their city's economic profile and tax revenue potential) than to estimate transfers received, which depend on exogenous factors that are not easily observed. Furthermore, the educational level of voters is crucial to their cognitive ability to process the information available.

It is therefore useful to test the following hypothesis:

HYPOTHESIS 2: the fiscal effects on the probability of reelection depend on the voters' educational level.

We adopted the same technical procedures used before; they are shown in Table 3 .

19 Mieszkowski and Oakland (1979). 
Table 3 - Probability of Mayor Being Re-Elected With Different Sample (Years of Schooling)

\begin{tabular}{|c|c|c|c|c|}
\hline \multirow[t]{2}{*}{$\begin{array}{l}\text { Independent } \\
\text { Variables }\end{array}$} & $\begin{array}{l}\text { Probit-High } \\
\text { Literacy } \\
(P=0.65)\end{array}$ & $\begin{array}{c}\text { Probit-Heckman- } \\
\text { High } \\
\text { Literacy } \\
(P=0.55)\end{array}$ & $\begin{array}{l}\text { Probit-Low } \\
\text { Literacy } \\
(\mathrm{P}=0.60)\end{array}$ & $\begin{array}{c}\text { Probit-Heckman } \\
\text { Low } \\
\text { Literacy } \\
(\mathrm{P}=0.71)\end{array}$ \\
\hline & $(\mathrm{l})$ & (II) & (III) & (IV) \\
\hline \multicolumn{5}{|l|}{ Current Fiscal Result (\%change) } \\
\hline Tax Revenue (\%change) & $\begin{array}{c}-0.00008 \\
(-0.02)\end{array}$ & $\begin{array}{l}0.001 \\
(0.26)\end{array}$ & $\begin{array}{l}0.002 \\
(1.27)\end{array}$ & $\begin{array}{l}0.001 \\
(1.01)\end{array}$ \\
\hline Current Expenditure (\%change) & $\begin{array}{c}0.18 \\
(1.60)\end{array}$ & $\begin{array}{l}0.28^{\star *} \\
(2.07)\end{array}$ & $\begin{array}{l}0.51^{*} \\
(3.55)\end{array}$ & $\begin{array}{l}0.26^{\star *} \\
(2.27)\end{array}$ \\
\hline \multicolumn{5}{|l|}{ Current Transfers (\% change) } \\
\hline $\begin{array}{l}\text { Debt(difference in \% of Total } \\
\text { Revenue) }\end{array}$ & $\begin{array}{l}-0.26^{\star} \\
(-2.13)\end{array}$ & $\begin{array}{l}-0.22 \\
(-1.59)\end{array}$ & $\begin{array}{l}-0.08 \\
(-0.63)\end{array}$ & $\begin{array}{l}-0.12 \\
(-1.24)\end{array}$ \\
\hline Debt $_{98}(\%$ of Total Revenue $)$ & $\begin{array}{l}-0.23^{*} \\
(-2.03)\end{array}$ & $\begin{array}{l}-0.18 \\
(-1.40)\end{array}$ & $\begin{array}{c}-0.07 \\
(-0.63)\end{array}$ & $\begin{array}{l}-0.11 \\
(-1.55)\end{array}$ \\
\hline Control Variables & YES & YES & YES & YES \\
\hline Observations & 584 & 819 & 604 & 819 \\
\hline Censored Observation & & 235 & & 215 \\
\hline Uncensored Observations & & 584 & & 604 \\
\hline Log-likelihood & -344.75 & & -362.16 & \\
\hline Rho & & 0.54 & & -0.92 \\
\hline Prob. Indep of Equations & & 0.23 & & 0.04 \\
\hline Pseudo $\mathrm{R}^{2}$ & 0.09 & & 0.11 & \\
\hline Observed P & 0.64 & & 0.58 & \\
\hline Predicted $\mathrm{P}$ & 0.65 & & 0.60 & \\
\hline
\end{tabular}

Notes: ${ }^{* * *} 10 \%,{ }^{* *} 5 \%,{ }^{*} 1 \%$. For each independent variable we report $(\mathrm{dF} / \mathrm{dx})$, i.e., the marginal change in the probability of success for the average values of the independent variables. In parentheses, we report the t-statistics based on robust, heteroscedastic-consistent standard errors (Huber/White/Sandwich).

We do not show the results of the control variables, but we consider the same variables used in column VI in Table 2. The references to a high literacy rate in the first line include municipalities from the sample with a high percentage of adult literacy (over 70\%). In contrast, a low literacy rate includes municipalities from the sample that have a reduced percentage of adult literacy (below 30\%). 
It is important to observe that there is no selection process for the "high literacy" group. Therefore, for this group we consider the results in column (I) of Table 3: simple Probit model. For the "low literacy" group the Heckman selection model indicates dependency between the candidacy and the reelection model. For this reason we consider the coefficients shown in column (IV).

With regard to the probability of a mayor being reelected, the first line of the Table shows that there is a difference between municipalities with high and low literacy rates (0.65 and 0.71): illiterate voters tend to reelect their mayors more frequently. In "high literacy" municipalities the increase in expenditure in the term Current Expenditure (\%change) is not significant, but it is significant and much more important to municipalities that have a low literacy rate.

Furthermore, we can see that the "high literacy" electorate behaves in a typical, fiscally-conservative manner, since it punishes mayors who increase debt during their term in office. The "low literacy" group does not present a significant coefficient for debt variables.

Therefore, we can hypothesize that education level is an important determinant of voter behavior.

Peltzman (op. cit.) writes that American ballot results indicate fiscal conservativism because voters are wealthier and better informed than non-voters. Because the wealthier pay more taxes, there is a trend to vote for less spending and less taxes. $\mathrm{He}$ further argues that voters punish incumbents that increase social spending precisely because they favor non-voters.

The Brazilian case seems to be the opposite: voting is mandatory for the literate (including those whose literacy is limited to signing their names) and elective for the illiterate. This means that, unlike in the United States, a mass of poorly educated voters is required to cast their ballot. These voters pay no direct taxes, have little information about the indirect taxes they do pay, and have a great demand for welfare and public investment in their communities. This sets the stage for strong voter support for fiscal expansionism in municipalities. This being the case, hypothesis 2 is valid.

\section{Other Relevant Results}

We examined the possibility raised by Drazen and Eslava (op. cit.) that a successful election strategy might change spending composition immediately before a vote, 
by increasing public investment and reducing current expenditure. No variable indicating the share of investments in expenses ${ }^{20}$ provided a significant coefficient, which indicates that this pattern, which is found in Colombian municipalities, does not occur in Brazil.

We decomposed the change in current expenditure and total expenditure by year to check whether increased spending in the beginning, middle or end of the term had a different impact on the probability of reelection. We found that increased spending is positively and significantly correlated with the probability of reelection for every year of the term.

This seems to indicate that the phenomenon detected here is not that of classical "political budget cycles," but a preference for increased spending throughout the term. This reinforces the article's interpretation of the data; that the result springs from the fiscal federalism model and from a correlation of forces among federation entities that results in a soft budget constraint for all municipalities.

\section{Conclusions}

This article shows that Brazilian voters have a preference for mayors who increase public spending. These results reinforce the idea that there is no such thing as "uniform electoral behavior throughout the world": electoral choices depend on the incentives offered to voters. That is why different papers, considering different countries, find conflicting results: some point to a "fiscally conservative" profile of the electorate and others point in the direction of "fiscal profligacy".

In the Brazilian case we interpret this statistical evidence as a result of a fiscal federalism model, with a soft budget constraint on municipalities. In line with Rodden (op. cit.), we argue that the weakness of the budget constraint is a result of the combination of the great political weight of local interests in the National Congress; of the heterogeneity of municipalities, which enables a coalition of interests between large and small municipalities that organize to extract federal funds; excessive fiscal transfers; the municipalities' ability to manipulate transfer rules; and central government's inability to withstand pressures for bailouts and enforce binding legal constraints on sub-national indebtedness. Moreover, there is evidence that the population's low educational level has a greater impact on expenditure when compared to the average of municipalities and that a highly literate electora-

20 Appendix A contains the definition of public investment variable. The descriptive statistics of variables included in this section can be requested from the authors. 
te behaves in a typical, fiscally-conservative manner, since it punishes mayors who increase debt during their term in office.

We must bear in mind, however, that since 2000, the year of the elections analyzed here, some institutional advances have occurred. Approval of a fiscal responsibility act in that same year defined management parameters and created constraints and transparency requirements for municipal accounts. Above all, there is a commitment not to offer new bailouts and to apply stricter criteria to the approval of subnational indebtedness. A federal audit program on randomly selected municipalities has exposed cases of corrupt mayors and increased voter information levels. Ferraz and Finan (2005) show evidence of a reduced probability of reelection when the corruption these audits reveal increases. A federal decision has suspended the establishment of new municipalities until a federal law is passed that regulates the process; this reduces the municipalities' ability for manipulating federal transfer rules.

On the other hand, the municipalities' great ability to exert power at the federal level persists. Evaluation of the 2004 and 2008 municipal elections will allow us to determine whether the institutional changes have been strong enough and longlasting enough to buttress the budget constraint on mayors and promote significant changes in municipal voters' preference patterns.

\section{References}

AKHMEDOV, A.; ZHURAVSKAYA, E. Opportunistic political cycles: test in a young democracy setting. The Quarterly Journal of Economics, 119, p. 13011338, 2004.

ALESINA, A. et al. The political economy of fiscal adjustments. Brookings Papers on Economic Activity, v. 1998, n. 1, p. 197-266, 1998.

ANSELIN, L. Spatial econometrics: methods and models. London: Kluwer Academic Publishers, 1987.

ARVATE, P.R.; AVELINO, G.; TAVARES, J. Budget deficits and reelection prospects: voters as fiscal conservatives in a new democracy. Economic Letters, v. 102, n. 2, p. 125-127, 2009.

BOYES, W. J.; HOFFMAN, D.L.; LOW, S.A. An econometric analysis of the bank credit scoring problem. Journal of Econometrics, 40, p. 3-14, 1989.

BRENDER, A. The effect of fiscal performance on local government election results in Israel: 1989-1998. Journal of Public Economics, n. 87, p. 2.187-2.205, 2003. 
; DRAZEN, A. How do budget deficits and economic growth affect reelection prospects? Evidence from a large cross-section of countries. NBER Working Paper 11862, NBER, Cambridge MA, 2005.

CAREY, J.; SHUGART, M. Incentives to cultivate a personal vote: a rank ordering of electoral formulas. Electoral Studies, 14/4, 1995.

DRAZEN, A.; ESLAVA, M. Electoral manipulation via expenditure composition: theory and evidence, NBER Working Paper 11085, NBER, Cambridge MA, 2005.

IMF. A manual on government financial statistics. IMF, Washington D.C, 2003.

FERRAZ, C.; FINAN, F. Exposing corrupt politicians: the effect of Brazil's publicly released audits on electoral outcomes. University of California, Berckley, 2005. Unpublished. Available at: < http://www.are.berkeley.edu/ ferraz/exposing. pdf $>$.

GREENE, W. H. A statistical model for credit scoring. Discussion Paper: NYU Leonard N. Stern School of Business, 1992.

HECKMAN, J. Sample selection bias as a specification error. Econometrica, 47, p. 153-161, 1979.

MAINWARING, S. P. Rethinking party systems in the third wave of democratization: the case of Brazil. Stanford University Press, 1999.

MENDES, M. Aspectos institucionais da performance fiscal de estados e municípios. Revista de Economia Política, v. 19, n. 1 (73), jan-mar 1999.

MIESZKOWSKI, P.; OAKLAND, W. H. (Eds.). Fisca federalism and grants-in-aid. Washington DC: The Urban Institute, 1979.

NAKAGUMA, M.Y. Ciclos politicos e resultados eleitorais: um estudo sobre o comportamento do eleitor brasileiro. 2006. (Master Degree Thesis) - Universidade de São Paulo. Faculdade de Economia e Administração.

NISKANEN, W.A. Bureaucracy and representative government. Aldine-Atherton, 1971.

PELTZMAN, S. Voters as fiscal conservatives. Quarterly Journal of Economics, v. 100, n. 2, p. 327-361,1992.

POIRIER, D.J. Partial observability in bivariate probit models. Journal of Econometrics, 12, p. 209-217, 1980.

RODDEN, J. The dilemma of fiscal federalism: grants and fiscal performance around the world. American Journal of Political Science, v. 46, n. 3, p. 670687, 2002.

ROGOFF, K. Equilibrium political budget cycles. American Economic Review, San Francisco, v. 80, n. 1, p. 21-36, 1990.

; SIBERT, A. Elections and macroeconomic policy cycles. Review of Economic Studies, London, v. LV, p. 1-16, 1988. 
SAMUELS, D. Ambition, federalism, and legislative politics in Brazil. Cabridge University Press, 2003.

SCHLESINGER, J. Ambition and politics: political careers in the United States. Chicago: Rand McNally, 1966.

SHAH, A. The reform of intergovernmental fiscal relations in developing and emerging market economies. Washington (D.C.): World Bank, 1994.

SHIKIDA, C. Emancipação de distritos em Minas Gerais (1995) como conseqüência de um federalismo não tão preservador de mercados. Seminário Nova Economia Institucional. São Paulo, FEA-USP, 1998.

STEIN, E. Fiscal decentralization and government size in Latin America. Journal of Applied Economics, v. II, n. 2, p. 357-391, 1999.

STRUMPF, K. S. A predictive index for the flypaper effect. Journal of Public Economics, v. 69, p. 389-412, 1998.

TOMIO, F. R. L. Federalismo, municípios e decisões legislativas: a criação de municípios no Rio Grande do Sul. Revista de Sociologia Política, Curitiba, Paraná, Brasil, v. 24, p. 123-148, jun. 2005.

VAN DER VEN, W. P. M. M.; VAN PRAAG, B. M. S. The demand for deductibles in private health insurance: a probit model with sample selection. Journal of Econometrics, 17, p. 229-252, 1981.

VEIGA, L.G.; VEIGA, F.J. Does opportunism pay off? Economic Letters, v. 96, n. 2, p. 177-182, 2007.

ZALLER, J. R. The nature and origins of Mass Opinion. Cambridge University Press, 1992. 


\section{ANNEX A - Fiscal Variables}

\section{Descriptive Statistics, Variables' Definition, Sources}

\begin{tabular}{|c|c|c|c|c|c|c|c|}
\hline Variable & Description & Source & Obs & Mean & Std.Dev. & Min & Max \\
\hline $\begin{array}{l}\% \text { of State } \\
\text { Population }\end{array}$ & $\begin{array}{l}\text { Total population of the } \\
\text { municipality in } 2000 \text { divided } \\
\text { by the total population of } \\
\text { the state in } 2000\end{array}$ & $\begin{array}{l}\text { Brazilian Institute } \\
\text { of Geography and } \\
\text { Statistics (IBGE) - } \\
2000 \text { Census }\end{array}$ & 2732 & 0.004 & 0.02 & 0.00003 & 0.62 \\
\hline Area $\left(\mathrm{Km}^{2}\right)$ & $\begin{array}{l}\text { Geographic area of the } \\
\text { municipality }\left(\mathrm{km}^{2}\right)\end{array}$ & $\begin{array}{l}\text { Brazilian Institute } \\
\text { of Geography and } \\
\text { Statistics (IBGE) - } \\
2000 \text { Census }\end{array}$ & 2732 & 970.61 & 2198.22 & 2.85 & 41191.35 \\
\hline Bailout & $\begin{array}{l}\text { Dummy = } 1 \text { if the } \\
\text { municipality was bailed out } \\
\text { by Federal Government } \\
\text { and zero otherwise. } \\
\text { Program of municipal debt } \\
\text { reschedule of } 2001\end{array}$ & $\begin{array}{l}\text { National Treasury } \\
\text { Secretariat (STN) }\end{array}$ & 2732 & 0.03 & 0.19 & 0 & 1 \\
\hline Midwest & $\begin{array}{l}\text { Dummy }=1 \text { if the } \\
\text { municipality is located in } \\
\text { the Midwest region and } \\
\text { zero otherwise }\end{array}$ & $\begin{array}{l}\text { Brazilian Institute } \\
\text { of Geography and } \\
\text { Statistics (IBGE) - } \\
2000 \text { Census }\end{array}$ & 2732 & 0.08 & 0.28 & 0 & 1 \\
\hline $\begin{array}{l}\text { Current } \\
\text { Expenditure } \\
\text { (\%change) }\end{array}$ & See definition below & $\begin{array}{l}\text { National Treasury } \\
\text { Secretariat (STN) }\end{array}$ & 2732 & 0.28 & 0.17 & -0.23 & 1.87 \\
\hline $\begin{array}{l}\text { Current Fiscal } \\
\text { Result (\%change) }\end{array}$ & See definition below & $\begin{array}{l}\text { National Treasury } \\
\text { Secretariat (STN) }\end{array}$ & 2732 & -0.05 & 16.33 & -338.81 & 309.65 \\
\hline $\begin{array}{l}\text { Current Transfers } \\
\text { (\%change) }\end{array}$ & See definition below & $\begin{array}{l}\text { National Treasury } \\
\text { Secretariat (STN) }\end{array}$ & 2732 & 0.30 & 0.17 & -0.32 & 1.62 \\
\hline $\begin{array}{l}\text { Debt (difference } \\
\text { in } \% \text { of Total } \\
\text { Revenue) }\end{array}$ & See definition below & $\begin{array}{l}\text { National Treasury } \\
\text { Secretariat (STN) }\end{array}$ & 2732 & -0.04 & 0.22 & -7.33 & 1.54 \\
\hline $\begin{array}{l}\text { Debt } 98(\% \text { of } \\
\text { Total Revenue) }\end{array}$ & See definition below & $\begin{array}{l}\text { National Treasury } \\
\text { Secretariat (STN) }\end{array}$ & 2732 & 0.31 & 0.28 & 0 & 7.56 \\
\hline Elderly & $\begin{array}{l}\text { Dummy = } 1 \text { if mayor is } \\
\text { over } 70 \text { years old and zero } \\
\text { otherwise }\end{array}$ & $\begin{array}{l}\text { Brazilian Electoral } \\
\text { Court (TSE) }\end{array}$ & 2732 & 0.02 & 0.16 & 0 & 1 \\
\hline $\begin{array}{l}\text { Human } \\
\text { Development } \\
\text { Index } 00\end{array}$ & $\begin{array}{l}\text { Index of life quality based } \\
\text { on indicators of education, } \\
\text { health, income and housing } \\
\text { for the year } 2000\end{array}$ & $\begin{array}{l}\text { United Nations } \\
\text { Development } \\
\text { Program }\end{array}$ & 2732 & 0.72 & 0.07 & 0.46 & 0.91 \\
\hline Literacy (adults) & $\begin{array}{l}\text { Percentage of adult } \\
\text { population who declare } \\
\text { being able to read and write }\end{array}$ & $\begin{array}{l}\text { Brazilian Institute } \\
\text { of Geography and } \\
\text { Statistics (IBGE) }\end{array}$ & 2732 & 0.81 & 0.11 & 0.39 & 0.99 \\
\hline $\begin{array}{l}\text { Metropolitan } \\
\text { Region }\end{array}$ & $\begin{array}{l}\text { Dummy }=1 \text { if the } \\
\text { municipality belongs to a } \\
\text { metropolitan region and } \\
\text { zero otherwise }\end{array}$ & $\begin{array}{l}\text { Brazilian Institute } \\
\text { of Geography and } \\
\text { Statistics (IBGE) }\end{array}$ & 2732 & 0.09 & 0.29 & 0 & 1 \\
\hline North & $\begin{array}{l}\text { Dummy = } 1 \text { if the } \\
\text { municipality is located in } \\
\text { the North region and zero } \\
\text { otherwise }\end{array}$ & $\begin{array}{l}\text { Brazilian Institute } \\
\text { of Geography and } \\
\text { Statistics (IBGE) - } \\
2000 \text { Census }\end{array}$ & 2732 & & .184165 & 0 & 1 \\
\hline
\end{tabular}




\begin{tabular}{|c|c|c|c|c|c|c|c|}
\hline Variable & Description & Source & Obs & Mean & Std.Dev. & Min & Max \\
\hline $\begin{array}{l}\% \text { of State } \\
\text { Population }\end{array}$ & $\begin{array}{l}\text { Total population of the } \\
\text { municipality in } 2000 \text { divided } \\
\text { by the total population of } \\
\text { the state in } 2000\end{array}$ & $\begin{array}{l}\text { Brazilian Institute } \\
\text { of Geography and } \\
\text { Statistics (IBGE) - } \\
2000 \text { Census }\end{array}$ & 2732 & 0.004 & 0.02 & 0.00003 & 0.62 \\
\hline Northeast & $\begin{array}{l}\text { Dummy = } 1 \text { if the } \\
\text { municipality is located in } \\
\text { the Northeast region and } \\
\text { zero otherwise }\end{array}$ & $\begin{array}{l}\text { Brazilian Institute } \\
\text { of Geography and } \\
\text { Statistics (IBGE) - } \\
2000 \text { Census }\end{array}$ & 2732 & 0.20 & 0.40 & 0 & 1 \\
\hline New Municipality & $\begin{array}{l}\text { Dummy = } 1 \text { if the } \\
\text { municipality was created } \\
\text { between } 1993 \text { and 1996, } \\
\text { having its first election } \\
\text { in } 1996 \text { and the second } \\
\text { election in } 2000 \text { and zero } \\
\text { otherwise }\end{array}$ & $\begin{array}{l}\text { Brazilian Institute } \\
\text { of Geography and } \\
\text { Statistics (IBGE) }\end{array}$ & 2732 & 0.08 & 0.27 & 0 & 1 \\
\hline $\begin{array}{l}\text { Population } \\
\text { Growth }_{0091}\end{array}$ & $\begin{array}{l}\text { Population growth rate } \\
\text { between } 1991 \text { and } 2000\end{array}$ & $\begin{array}{l}\text { Brazilian Institute } \\
\text { of Geography and } \\
\text { Statistics (IBGE) } \\
\text { - } 1991 \text { and } 2000 \\
\text { Census }\end{array}$ & 2732 & 0.009 & 0.02 & -0.06 & 0.21 \\
\hline Population $_{00}$ & $\begin{array}{l}\text { Total population of the } \\
\text { municipality in } 2000\end{array}$ & $\begin{array}{l}\text { Brazilian Institute } \\
\text { of Geography and } \\
\text { Statistics (IBGE) - } \\
2000 \text { Census }\end{array}$ & 2732 & & & 873 & $1.04 \mathrm{e}+07$ \\
\hline Reelection & $\begin{array}{l}\text { Dummy = } 1 \text { if mayor } \\
\text { was reelected and zero } \\
\text { otherwise }\end{array}$ & $\begin{array}{l}\text { Brazilian Electoral } \\
\text { Court (TSE) }\end{array}$ & 2732 & 0.42 & 0.49 & 0 & 1 \\
\hline South & $\begin{array}{l}\text { Dummy = } 1 \text { if the } \\
\text { municipality is located in } \\
\text { the South region and zero } \\
\text { otherwise }\end{array}$ & $\begin{array}{l}\text { Brazilian Institute } \\
\text { of Geography and } \\
\text { Statistics (IBGE) - } \\
2000 \text { Census }\end{array}$ & 2732 & 0.30 & 0.46 & 0 & 1 \\
\hline State Capital & $\begin{array}{l}\text { Dummy = } 1 \text { if the } \\
\text { municipality is a state } \\
\text { capital and zero otherwise }\end{array}$ & Common Knowledge & 2732 & 0.004 & 0.06 & 0 & 1 \\
\hline Southeast & $\begin{array}{l}\text { Dummy = } 1 \text { if the } \\
\text { municipality is located in } \\
\text { the Southeast region and } \\
\text { zero otherwise }\end{array}$ & $\begin{array}{l}\text { Brazilian Institute } \\
\text { of Geography and } \\
\text { Statistics (IBGE) - } \\
2000 \text { Census }\end{array}$ & 2732 & 0.36 & 0.48 & 0 & 1 \\
\hline $\begin{array}{l}\text { Tax Revenue } \\
\text { (\%change) }\end{array}$ & See definition below & $\begin{array}{l}\text { National Treasury } \\
\text { Secretariat (STN) }\end{array}$ & 2732 & 0.39 & 5.41 & -1 & 268.86 \\
\hline $\begin{array}{l}\text { Urban Population } \\
\text { (\%) }\end{array}$ & $\begin{array}{l}\text { Urban municipal population } \\
\text { divided by total municipal } \\
\text { population }\end{array}$ & $\begin{array}{l}\text { Brazilian Institute } \\
\text { of Geography and } \\
\text { Statistics (IBGE) - } \\
2000 \text { Census }\end{array}$ & 2732 & 0.59 & 0.23 & 0 & 1 \\
\hline Votes 96 & $\begin{array}{l}\text { Percentage of votes } \\
\text { obtained by mayors who } \\
\text { were candidates in } 1996\end{array}$ & $\begin{array}{l}\text { Brazilian Electoral } \\
\text { Court (TSE) }\end{array}$ & 2732 & 52.15 & 9.88 & 22.92 & 90.60 \\
\hline Votes 00 & $\begin{array}{l}\text { Percentage of votes } \\
\text { obtained by mayors in } 2000\end{array}$ & $\begin{array}{l}\text { Brazilian Electoral } \\
\text { Court (TSE) }\end{array}$ & 1992 & 49.92 & 16.22 & 3 & 100 \\
\hline
\end{tabular}




\section{Complementary variables' definitions}

1) Total Fiscal Result (\%change)

$$
\left[\left(T R_{2000}+T F R_{1999}\right) /\left(T_{1 F R_{198}}+T F R_{1997}\right)\right]-1
$$

where TFR $R_{t}$ is the Total Fiscal Result in year $t$ ( $t$ should be 2000,1999,1998, and 1997). Similar definitions apply to the following variables: Current Fiscal Result (\% change), Tax Revenue (\%change), Current Expenditure (\% change), Total Expenditure (\% change), Investment (\% change). The variables are measured in Reais (base $=2000$ ).

2) Total Fiscal Result (difference)

$$
\left[\frac{\left(T F R_{2000}+T F R_{1999}\right)}{2}-\frac{\left(T F R_{1998}-T R F_{1997}\right)}{2}\right]
$$

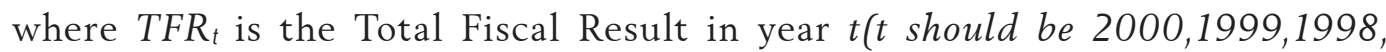
and 1997). Similar definitions apply to the following variables: Current Fiscal Result (difference), Tax Revenue (difference) Investment (difference), Current Expenditure (difference), Total Expenditure (difference). The variables are measured in Reais (base $=2000$ ).

3) Total Expenditure (mean 98-00/97)

$$
\frac{\sum_{t=1998}^{2000} T E_{t} / 3}{T E_{1997}}-1
$$

where $T E_{t}$ is the Total Expenditure in year $t$. Similar definitions apply to the following variables: Current Expenditure (mean 98-00/97), Investment (mean 98-00/97), Tax Revenue (mean 98-00/97), Current Transfers (mean 98-00/97), Total Transfers (mean 98-00/97), Current Fiscal Result (mean 98-00/97). The variables are measured in Reais (base $=2000)$. 
4) Total Expenditure (mean of yearly change)

$$
\left(\sum_{t=1997}^{1999} \frac{T E_{t+1}}{T E_{t}}-1\right) /
$$

where $T E_{t}$ is the Total Expenditure in year $t$. Similar definitions apply to the following variables: Current Expenditure (mean of yearly change), Tax Revenue (mean of yearly change). The variables are measured in Reais (base $=2000$ ).

\section{5) Debt98 (\% of Total Revenue)}

$$
\frac{T D_{1998}}{T R_{1998}}
$$

where $T D_{1998}$ is the Total Debt in 1998 and $T R_{98}$ is the Total Revenue in 1998. The variables are measured in Reais (base $=2000)$. Since there is no available data for debt in 1997, Debt 98 is taken as a proxy for municipal debt at the beginning of the first term.

6) Debt (difference in \% of Total Revenue)

$$
\frac{T D_{2000}}{T R_{2000}}-\frac{T D_{1998}}{T R_{1998}}
$$

where $T D_{t}$ is the Total Debt in year $t$ and $T R_{t}$ is the Total Revenue in year $t$. The variables are measured in Reais (base $=2000$ ).

\section{7) Debt (\% change)}

$$
\frac{T D_{2000}}{T D_{1998}}-1
$$

where $T D_{t}$ is the Total Debt in year $t$. The variables are measured in Reais (base $=2000)$.

The monetary values of years 1997 to 1999 were inflated to prices of 2000 using IPCA the price index (broad consumer price index) calculated by the IBGE. Flow 
variables, like expenditure and revenue, were inflated using the accumulated index from July of year $t$ to June of year 2000. The stock variable "debt", the nominal value of which refers to December of each year, was inflated using the accumulated index from January of year $t+1$ to December of the year 2000 .

\section{Correlation matrix}

\begin{tabular}{|c|c|c|c|c|c|c|}
\hline Variables & $\begin{array}{l}\% \text { of State } \\
\text { Population }\end{array}$ & $\begin{array}{l}\text { Area } \\
\left(\mathrm{Km}^{2}\right)\end{array}$ & Bailout & Candidate & Midwest & $\begin{array}{l}\text { Current Expenditure } \\
\text { (\%change) }\end{array}$ \\
\hline$\%$ of State Population & 1.0000 & & & & & \\
\hline Area $\left(\mathrm{Km}^{2}\right)$ & 0.1635 & 1.0000 & & & & \\
\hline Bailout & 0.0994 & 0.0547 & 1.0000 & & & \\
\hline Candidate & 0.0054 & -0.0093 & -0.0079 & 1.0000 & & \\
\hline Midwest & 0.0211 & 0.2797 & 0.0384 & -0.0941 & 1.0000 & \\
\hline $\begin{array}{l}\text { Current Expenditure } \\
\text { (\%change) }\end{array}$ & -0.0242 & 0.1032 & -0.0703 & 0.1534 & 0.0605 & 1.0000 \\
\hline $\begin{array}{l}\text { Current Fiscal Result } \\
\text { (\%change) }\end{array}$ & -0.0064 & 0.0090 & 0.0080 & 0.0170 & -0.0016 & 0.0205 \\
\hline $\begin{array}{l}\text { Current Transfers } \\
\text { (\%change) }\end{array}$ & 0.0315 & 0.0976 & -0.0053 & 0.1503 & 0.0162 & 0.6824 \\
\hline $\begin{array}{l}\text { Debt (difference in \% of } \\
\text { Total Revenue) }\end{array}$ & -0.0475 & -0.0308 & 0.0149 & 0.0334 & -0.0479 & -0.0009 \\
\hline $\begin{array}{l}\text { Debt } 98(\% \text { of Total } \\
\text { Revenue) }\end{array}$ & 0.0699 & 0.0216 & 0.2371 & -0.0084 & 0.0700 & -0.2550 \\
\hline Elderly & -0.0067 & -0.0096 & -0.0247 & -0.1135 & -0.0349 & -0.0033 \\
\hline $\begin{array}{l}\text { Human Development } \\
\text { Index00 }\end{array}$ & 0.0656 & -0.0703 & 0.1826 & -0.0942 & 0.0710 & -0.3419 \\
\hline Literacy (adults) & 0.0623 & -0.0638 & 0.1469 & -0.0903 & 0.0576 & -0.3319 \\
\hline Metropolitan Region & 0.1241 & -0.0878 & 0.1116 & 0.0251 & -0.0013 & -0.0399 \\
\hline North & 0.2201 & 0.3720 & -0.0389 & 0.0224 & -0.0548 & 0.0340 \\
\hline Northeast & 0.0284 & -0.0270 & -0.0760 & 0.0931 & -0.1517 & 0.2931 \\
\hline New Municipality & -0.0517 & -0.0665 & -0.0657 & 0.0958 & -0.0472 & 0.2658 \\
\hline Population Growth 0091 & 0.1213 & 0.1569 & 0.0622 & 0.0791 & 0.1228 & 0.1677 \\
\hline Population $_{00}$ & 0.6350 & 0.0563 & 0.2501 & -0.0048 & -0.0251 & -0.0434 \\
\hline Reelection & 0.0109 & -0.0130 & -0.0070 & 0.5259 & -0.0281 & 0.1637 \\
\hline South & -0.0493 & -0.1400 & -0.0351 & -0.0840 & -0.1742 & -0.2476 \\
\hline State Capital & 0.6250 & 0.0293 & 0.1134 & -0.0057 & -0.0176 & -0.0419 \\
\hline $\begin{array}{l}\text { Tax Revenue } \\
\text { (\%change) }\end{array}$ & -0.0051 & -0.0124 & -0.0068 & 0.0191 & -0.0072 & 0.0375 \\
\hline Urban Population (\%) & 0.1658 & 0.0007 & 0.2179 & 0.0606 & 0.1052 & -0.1621 \\
\hline Votes 96 & -0.0548 & -0.0708 & -0.0586 & -0.0671 & 0.0110 & 0.0011 \\
\hline Votes 00 & -0.0456 & -0.0382 & -0.0328 & - & -0.0249 & 0.1961 \\
\hline
\end{tabular}




\begin{tabular}{|c|c|c|c|c|c|c|c|}
\hline Variables & $\begin{array}{l}\text { Current } \\
\text { Fiscal Result } \\
\text { (\%change) }\end{array}$ & $\begin{array}{l}\text { Current } \\
\text { Transfers } \\
\text { (\%change) }\end{array}$ & $\begin{array}{c}\text { Debt } \\
\text { (difference } \\
\text { in \% of Total } \\
\text { Revenue) }\end{array}$ & $\begin{array}{l}\text { Debt98(\% } \\
\text { of Total } \\
\text { Revenue) }\end{array}$ & Elderly & $\begin{array}{l}\text { Human } \\
\text { Development } \\
\text { Index00 }\end{array}$ & $\begin{array}{l}\text { Literacy } \\
\text { (adults) }\end{array}$ \\
\hline $\begin{array}{l}\text { Current } \\
\text { Fiscal Result } \\
\text { (\%change) }\end{array}$ & 1.0000 & & & & & & \\
\hline $\begin{array}{l}\text { Current } \\
\text { Transfers } \\
\text { (\%change) }\end{array}$ & 0.0517 & 1.0000 & & & & & \\
\hline $\begin{array}{l}\text { Debt (difference } \\
\text { in } \% \text { of Total } \\
\text { Revenue) }\end{array}$ & -0.0276 & -0.1117 & 1.0000 & & & & \\
\hline $\begin{array}{l}\text { Debt98(\% of } \\
\text { Total Revenue) }\end{array}$ & 0.0030 & -0.0615 & -0.2774 & 1.0000 & & & \\
\hline Elderly & -0.0700 & -0.0050 & -0.0250 & 0.0212 & 1.0000 & & \\
\hline $\begin{array}{l}\text { Human } \\
\text { Development } \\
\text { Index00 }\end{array}$ & -0.0080 & -0.2559 & -0.0166 & 0.2075 & 0.0129 & 1.0000 & \\
\hline Literacy (adults) & -0.0073 & -0.2487 & -0.0176 & 0.2024 & -0.0030 & 0.9459 & 1.0000 \\
\hline $\begin{array}{l}\text { Metropolitan } \\
\text { Region }\end{array}$ & -0.0261 & 0.0552 & -0.0123 & 0.1237 & -0.0149 & 0.2354 & 0.2480 \\
\hline North & 0.0008 & 0.0502 & -0.0382 & -0.0556 & -0.0249 & -0.1151 & -0.0707 \\
\hline Northeast & 0.0037 & 0.2791 & -0.0038 & -0.1614 & -0.0110 & -0.7308 & -0.7761 \\
\hline New Municipality & 0.0065 & 0.0946 & 0.0343 & -0.2599 & -0.0150 & -0.1574 & -0.1171 \\
\hline $\begin{array}{l}\text { Population } \\
\text { Growth }_{0091}\end{array}$ & 0.0136 & 0.2421 & 0.0004 & 0.0013 & -0.0104 & 0.1636 & 0.1711 \\
\hline Population $_{00}$ & -0.0118 & 0.0274 & -0.0032 & 0.1524 & 0.0035 & 0.1704 & 0.1561 \\
\hline Reelection & 0.0195 & 0.0938 & -0.0330 & -0.1240 & -0.0588 & -0.1397 & -0.1528 \\
\hline $\begin{array}{l}\text { Reelection Micro } \\
\text { Region }\end{array}$ & -0.0017 & 0.1043 & -0.0118 & -0.0619 & -0.0251 & -0.3308 & -0.3625 \\
\hline South & -0.0132 & -0.2234 & -0.0178 & 0.0683 & 0.0110 & 0.4104 & 0.4258 \\
\hline State Capital & 0.0013 & -0.0381 & 0.0131 & 0.0167 & -0.0080 & 0.0754 & 0.0633 \\
\hline Southeast & 0.0096 & -0.0631 & 0.0604 & 0.0613 & 0.0277 & 0.2612 & 0.2758 \\
\hline $\begin{array}{l}\text { Tax Revenue } \\
\text { (\%change) }\end{array}$ & -0.0032 & 0.0175 & 0.0071 & -0.0430 & -0.0040 & -0.0607 & -0.0597 \\
\hline $\begin{array}{l}\text { Urban } \\
\text { Population (\%) }\end{array}$ & 0.0004 & -0.0280 & 0.0007 & 0.3084 & 0.0227 & 0.4882 & 0.4387 \\
\hline Votes96 & -0.0148 & -0.0542 & -0.0184 & -0.0977 & -0.0525 & -0.0685 & -0.0688 \\
\hline Votes00 & 0.0075 & 0.1072 & -0.0468 & -0.1731 & -0.0754 & -0.2046 & -0.2136 \\
\hline
\end{tabular}




\begin{tabular}{|c|c|c|c|c|c|c|c|}
\hline Variables & $\begin{array}{c}\text { Metropolita } \\
\text { Region }\end{array}$ & North & Northeast & $\begin{array}{c}\text { New } \\
\text { Municipality }\end{array}$ & $\begin{array}{l}\text { Population } \\
\text { Growth }_{0091}\end{array}$ & Population $_{00}$ & Reelection \\
\hline $\begin{array}{l}\text { Metropolitan } \\
\text { Region }\end{array}$ & 1.0000 & & & & & & \\
\hline North & -0.0571 & 1.0000 & & & & & \\
\hline Northeast & -0.1148 & -0.1083 & 1.0000 & & & & \\
\hline $\begin{array}{l}\text { New } \\
\text { Municipality }\end{array}$ & -0.0445 & -0.0135 & 0.0313 & 1.0000 & & & \\
\hline $\begin{array}{l}\text { Population } \\
\text { Growth } \\
0091\end{array}$ & 0.3253 & 0.0937 & -0.0416 & 0.0409 & 1.0000 & & \\
\hline Population $_{00}$ & 0.2830 & 0.0452 & -0.0048 & -0.0766 & 0.1229 & 1.0000 & \\
\hline Reelection & -0.0015 & -0.0208 & 0.1729 & 0.1356 & -0.0019 & 0.0274 & 1.0000 \\
\hline South & 0.1213 & -0.1244 & -0.3441 & 0.0384 & -0.1413 & -0.0466 & 0.0068 \\
\hline State Capital & 0.1377 & 0.0708 & 0.0218 & -0.0212 & 0.0280 & 0.7701 & 0.0374 \\
\hline Southeast & 0.0101 & -0.1540 & -0.4260 & -0.0325 & 0.0654 & 0.0431 & -0.1334 \\
\hline $\begin{array}{l}\text { Tax Revenue } \\
\text { (\%change) }\end{array}$ & -0.0120 & 0.0051 & 0.0639 & 0.0294 & 0.0183 & -0.0116 & 0.0279 \\
\hline $\begin{array}{l}\text { Urban } \\
\text { Population (\%) }\end{array}$ & 0.2821 & -0.0548 & -0.2518 & -0.2757 & 0.3422 & 0.2743 & -0.1345 \\
\hline Votes96 & -0.1386 & -0.0768 & 0.0088 & 0.1164 & -0.1202 & -0.0833 & 0.2185 \\
\hline Votes 00 & -0.0279 & -0.0408 & 0.1862 & 0.1792 & -0.0269 & -0.0573 & 0.6677 \\
\hline Variables & & South & State Capital & Southeast & $\begin{array}{l}\text { Tax Revenue } \\
\text { (\%change) }\end{array}$ & $\begin{array}{c}\text { Urban } \\
\text { Population (\%) }\end{array}$ & Votes96 \\
\hline South & & 1.0000 & & & & & \\
\hline State Capital & & -0.0223 & 1.0000 & & & & \\
\hline Southeast & & -0.4893 & -0.0167 & 1.0000 & & & \\
\hline Tax Revenue (\%c & change) & -0.0275 & -0.0040 & -0.0282 & 1.0000 & & \\
\hline Urban Population & $n(\%)$ & -0.1274 & 0.1017 & 0.3029 & -0.0519 & 1.0000 & \\
\hline Votes96 & & 0.1020 & 0.0114 & -0.0781 & -0.0006 & -0.1738 & 1.0000 \\
\hline Votes 00 & & -0.0078 & -0.0046 & -0.1253 & 0.0306 & -0.2018 & 0.3281 \\
\hline
\end{tabular}

